\title{
Pengaruh Penyuluhan Terhadap Minat Calon Akseptor KB Vasektomi di Puskesmas Kedawung Kabupaten Cirebon
}

\author{
Ade Rahayu Prihartini ${ }^{1}$ \\ ${ }^{1}$ Prodi Diploma III kebidanan Poltekes Bhakti Pertiwi Husada Cirebon \\ Jl. Kampung Melati 6A Kesambi Kota Cirebon \\ nenkdiva@gmail.com
}

\begin{abstract}
Abstrak, Penggunaan KB vasektomi sampai saat ini jumlahnya minim. Berdasarkan data laporan Pencapaian Peserta KB Aktif Kecamatan Kedawung Kabupaten Cirebon tahun 2017, diketahui bahwa jumlah PUS di wilayah Kecamatan Kedawung sebanyak 8.965 orang dan yang menggunakan KB Vasektomi hanya 4,7\% dari jumlah PUS. Penelitian ini bertujuan untuk mengetahui pengaruh penyuluhan terhadap minat calon akseptor KB Vasektomi di Puskesmas Kedawung Kabupaten Cirebon Tahun 2018. Penelitian ini menggunakan jenis penelitian kuantitatif dengan desain cross sectional. Sampel dalam penelitian ini adalah pria pasangan usia subur di Wilayah Puskesmas Kedawung Kabupaten Cirebon sebanyak 98 orang. Analisis datanya menggunakan analisis univariat dengan distribusi frekuensi dan analisis bivariat dengan uji chi square. Hasil penelitian menunjukkan bahwa responden di Wilayah Puskesmas Kedawung Kabupaten Cirebon yang tidak hadir penyuluhan tentang KB Vasektomi sebanyak 37 orang $(37,8 \%)$ dan yang hadir sebanyak 61 orang $(62,2 \%)$. Responden di Wilayah Puskesmas Kedawung Kabupaten Cirebon yang tidak minat menggunakan KB vasektomi sebanyak 70 orang $(70,7 \%)$ dan yang minat untuk menggunakan KB vasektomi sebanyak 28 orang (28,3\%). Terdapat pengaruh penyuluhan terhadap Minat Calon Akseptor KB Vasektomi di Puskesmas Kedawung Kabupaten Cirebon Tahun 2018 dengan p = 0,002.
\end{abstract}

Kata Kunci : Penyuluhan, Minat, KB Vasektomi

\begin{abstract}
The use of vasectomy $K B$ is minimal. Based on data from the report on the Achievement of Active KB Participants in the Kedawung District of Cirebon Regency in 2017, it is known that the number of EFA in the Kedawung Subdistrict is 8,965 people and that using Vasectomy $K B$ is only $4.7 \%$ of the total EFA. This study aims to determine the effect of counseling on the interest of prospective acceptors of Vasectomy KB at the Kedawung Health Center in Cirebon District in 2018. This research uses quantitative research with cross sectional design. The sample in this study were men of reproductive age in the Kedawung Community Health Center in Cirebon District as many as 98 people. Data analysis used univariate analysis with frequency distribution and bivariate analysis with chi square test. The results showed that respondents in the Kedawung Community Health Center in Cirebon District who were absent counseling about Vasectomy KB were 37 people (37.8\%) and 61 were present (62.2\%). Respondents in the Kedawung Community Health Center in Cirebon Regency were not interested in using a vasectomy KB as many as 70 people (70.7\%) and those who were interested in using vasectomy were 28 people (28.3\%). There is an influence of counseling on the Interest of Vasectomy KB Acceptor Candidates in the Kedawung Health Center in Cirebon District in 2018 with $p=0.002$.
\end{abstract}

Keywords: Counseling, Interest, KB Vasectomy

\section{PENDAHULUAN}

Keluarga Berencana (KB) merupakan salah satu pelayanan kesehatan preventif yang paling dasar dan utama bagi perempuan, meskipun tidak selalu diakui demikian. Peningkatan dan perluasan pelayanan KB merupakan salah satu usaha untuk menurunkan angka kesakitan dan kematian ibu yang sedemikian tinggi akibat kehamilan dan melahirkan. Untuk optimalisasi manfaat kesehatan $\mathrm{KB}$, pelayanan tersebut harus disediakan bagi perempuan 
dengan cara menggabungkan dan memenuhi kebutuhan pelayanan kesehatan reproduksi utama dengan yang lainnya (Badan Koordinasi Keluarga Berencana Nasional, 2016).

Ketersediaan layanan KB bagi perempuan terdapat dalam beberapa metode, dan perempuan harus dapat menimbang berbagai faktor dalam memilih metode KB yang sesuai bagi dirinya, termasuk status kesehatan mereka, efek samping potensial suatu metode, konsekuensi terhadap kehamilan yang tidak diinginkan, besarnya keluarga yang diinginkan, kerjasama pasangan, dan norma budaya mengenai kemampuan mempunyai anak (Handayani, 2014).

Dengan semakin berkembangnya program KB yang dicanangkan oleh pemerintah, alat kontrasepsi pun semakin berkembang. Berbagai pilihan alat kontrasepsi ditawarkan kepada masyarakat. Dari mulai yang sederhana sampai yang permanen/mantap, yaitu mulai pil, suntik, spiral dan Intra Uterine Device (IUD). Ada jenis kontrasepsi lain, yaitu vasektomi untuk pria dan tubektomi untuk perempuan. Namun 2 jenis alat kontrasepsi ini masih jarang dipilih oleh masyarakat, sebab dengan memiliki alat kontrasepsi mantap tersebut maka seseorang tidak bisa lagi memiliki anak (Kementerian Kesehatan RI, 2017).

Berdasarkan data Kementerian Kesehatan RI pada tahun 2016, tercatat jumlah peserta KB secara nasional mencapai 35.795.560 akseptor. Peserta KB yang menggunakan kondom sebanyak 1.131.373 akseptor (3,16\%), Pil sebanyak 8.447 .972 akseptor (23,60\%), Suntikan sebanyak 17.104 .340 akseptor (47,78\%), Intra Uterine Device (IUD) sebanyak 3.840.156 akseptor (10,73\%), Implan sebanyak 3.788.149 akseptor (10,58\%), Tubektomi sebanyak 1.249.364 akseptor (3,49\%) dan Vasektomi sebanyak 234.206 akseptor (0,65\%) (Kementerian Kesehatan RI, 2017).

Propinsi di Indonesia dengan jumlah akseptor terbanyak pada tahun 2017 terdapat di Propinsi Jawa Barat yaitu mencapai 9.541.148 akseptor. Akseptor yang menggunakan kondom sebanyak 123.898 akseptor (1,74\%), Pil sebanyak 1.827 .262 akseptor (25,68\%), Suntikan sebanyak 3.647.005 akseptor (51,26\%), IUD sebanyak 855.911 akseptor (12,03\%), Implan sebanyak 411.062 akseptor (5.78\%), Tubektomi sebanyak 192.910 akseptor (2,71\%) dan Vasektomi sebanyak 56.208 akseptor (0,79\%) (Dinas Kesehatan Propinsi Jawa Barat, 2017).

Berdasarkan data laporan Pencapaian Peserta KB Aktif Kecamatan Kedawung Kabupaten Cirebon tahun 2017, diketahui bahwa jumlah PUS di wilayah Kecamatan Kedawung sebanyak 8.965 orang, Jumlah PUS yang menggunakan KB baik hormonal maupun non hormonal sebanyak 6.769 orang (75,50\%). Akseptor KB yang menggunakan Vasektomi sebanyak 319 orang atau hanya 4,7\% dari jumlah PUS.

Walaupun vasektomi adalah cara KB paling efektif, tidak mengganggu hubungan seks, aman, dan biaya operasi yang relatif murah, tetapi pada kenyataannya peserta vasektomi lebih sedikit dibandingkan tubektomi (sterilisasi wanita) (Badan Koordinasi Keluarga Berencana Nasional, 2016). Rendahnya partisipasi pria dalam KB dan kesehatan reproduksi pada dasarnya tidak terlepas dari operasional program KB yang selama ini dilaksanakan mengarah pada wanita sebagai sasaran. Demikian juga masalah penyediaan alat kontrasepsi yang hampir semuanya untuk wanita, sehingga pola pikir masyarakat mempunyai persepsi yang dominan yakni yang hamil dan melahirkan adalah wanita, maka wanitalah yang harus menggunakan alat kontrasepsi. Oleh sebab itu, semenjak tahun 2000 pemerintah telah melakukan berbagai upaya untuk meningkatkan partisipasi pria dalam keluarga berencana dan kesehatan reproduksi melalui kebijakan yang telah ditetapkan (Kementerian Kesehatan RI, 2017).

Penggunaan vasektomi kurang dapat berkembang sebagaimana yang diharapkan. Rendahnya minat dalam penggunaan metode kontrasepsi vasektomi diakibatkan oleh adanya kekhawatiran para bapak/ suami setelah vasektomi mereka akan kehilangan kejantanannya. Belum membudayanya penggunaan vasektomi sebagai alat kontrasepsi disebabkan antara lain karena kondisi lingkungan sosial, budaya, masyarakat dan keluarga yang masih menganggap partisipasi pria belum atau tidak penting dilakukan, pengetahuan dan kesadaran pria dan keluarganya dalam ber $\mathrm{KB}$ rendah dan keterbatasan penggunaan pelayanan kontrasepsi pria masih terbatas (Badan Koordinasi Keluarga Berencana Nasional, 2016).

Penelitian Nesti (2014), faktor-faktor yang berhubungan dengan partisipasi pria dalam pemakaian kontrasepsi di kelurahan Mojosongo kecamatan Jebres menunjukan ada hubungan antara persepsi (nilai $\mathrm{p}=0,000$ ) dan dukungan istri (nilai $\mathrm{p}=0,000$ ) terhadap partisipasi pria dalam pemakaian kontrasepsi. 
Berdasarkan uraian tersebut maka peneliti tertarik untuk melakukan penelitian tentang "Pengaruh Penyuluhan Terhadap Minat Calon Akseptor KB Vasektomi di Puskesmas Kedawung Kabupaten Cirebon Tahun 2018.”

\section{METODE PENELITIAN}

Penelitian ini adalah penelitian kuantitatif dengan menggunakan pendekatan atau desain penelitian cross sectional. Populasi dalam penelitian adalah pria dari pasangan usia subur yang belum menggunakan KB vasektomi di Puskesmas Kedawung Kabupaten Cirebon sebanyak 4.263 orang dan sampelnya sebanyak 98 orang dengan teknik yang digunakan adalah simple random sampling. Pengumpulan datanya menggunakan lembar observasi dan kuesioner. Analisis datanya menggunakan analisis univariat dan bivariat.

\section{HASIL PENELITIAN}

Tabel. 1

Distribusi Frekuensi Responden Berdasarkan yang Hadir pada Kegiatan Penyuluhan

\begin{tabular}{|c|c|c|}
\hline Penyuluhan & Frekuensi & Presentase \\
\hline Tidak hadir & 37 & 37.8 \\
\hline Hadir & 61 & 62.2 \\
\hline Jumlah & $\mathbf{9 8}$ & $\mathbf{1 0 0 . 0}$ \\
\hline
\end{tabular}

Dari data menurut tabel 1 responden yang tidak hadir sebanyak 37 orang $(37,8 \%)$ dan yang hadir sebanyak 61 orang $(62,2 \%)$. Hal ini menunjukkan bahwa sebagian besar responden hadir pada kegiatan penyuluhan tentang KB vasektomi yang dilakukan di Wilayah Puskesmas Kedawung Kabupaten Cirebon.

Tabel. 2

Distribusi Frekuensi Responden Berdasarkan Minat Calon Akseptor KB Vasektomi

\begin{tabular}{|c|c|c|}
\hline $\begin{array}{c}\text { Minat } \\
\text { Responden }\end{array}$ & Frekuensi & Presentase \\
\hline Tidak minat & 70 & 70.7 \\
\hline Minat & 28 & 28.3 \\
\hline Jumlah & $\mathbf{9 8}$ & $\mathbf{1 0 0 . 0}$ \\
\hline
\end{tabular}

Dari data menurut tabel 2 responden yang tidak minat menggunakan KB vasektomi sebanyak 70 orang $(70,7 \%)$ dan yang minat untuk menggunakan KB vasektomi sebanyak 28 orang $(28,3 \%)$. Hal ini menunjukkan bahwa sebagian besar responden di Wilayah Puskesmas Kedawung Kabupaten Cirebon tidak berminat untuk menggunakan KB vasektomi.

Tabel 3

Pengaruh Penyuluhan terhadap Minat Calon Akseptor KB Vasektomi

\begin{tabular}{|c|c|c|c|c|c|c|}
\hline \multirow{2}{*}{$\begin{array}{c}\text { Penyuluha } \\
\text { n }\end{array}$} & \multicolumn{4}{|c|}{$\begin{array}{c}\text { Minat Calon } \\
\text { Akseptor KB } \\
\text { Vasektomi }\end{array}$} & \multicolumn{2}{c|}{ Jumlah } \\
\cline { 2 - 7 } & $\begin{array}{c}\text { Tidak } \\
\text { minat }\end{array}$ & \multicolumn{2}{c|}{ Minat } & \multicolumn{2}{c|}{} \\
\cline { 2 - 7 } & $\mathbf{f}$ & $\mathbf{\%}$ & $\mathbf{f}$ & $\mathbf{\%}$ & $\mathbf{f}$ & $\%$ \\
\hline \hline Tidak hadir & 33 & 89.2 & 4 & 10.8 & 37 & 100 \\
\hline Hadir & 37 & 60.7 & 24 & 39.3 & 61 & 100 \\
\hline Jumlah & $\mathbf{7 0}$ & $\mathbf{7 1 . 4}$ & $\mathbf{2 8}$ & $\mathbf{2 8 .}$ & $\mathbf{9 8}$ & $\mathbf{1 0 0}$ \\
\hline \multicolumn{6}{|c|}{ P value $=\mathbf{0 , 0 0 2}$} \\
\hline
\end{tabular}


Berdasarkan tabel 3 menunjukkan bahwa responden yang tidak hadir penyuluhan dan berminat menggunakan KB vasektomi sebanyak 4 orang (10.8\%) lebih sedikit dibanding dengan responden yang hadir penyuluhan dan berminat menggunakan KB vasektomi sebanyak 24 orang (39,3\%). Hasil penghitungan statistik dengan uji chi square diperoleh $\rho$ value $=0,002$ yang berarti $\rho$ value $<\alpha(0,05)$, sehingga hipotesis nol ditolak. Dengan demikian maka terdapat pengaruh penyuluhan terhadap Minat Calon Akseptor KB Vasektomi di Puskesmas Kedawung Kabupaten Cirebon.

\section{PEMBAHASAN}

1. Gambaran Penyuluhan di Puskesmas Kedawung Kabupaten Cirebon

Berdasarkan hasil penelitian menunjukkan bahwa sebagian besar responden hadir pada kegiatan penyuluhan tentang KB vasektomi yang dilakukan di Wilayah Puskesmas Kedawung Kabupaten Cirebon.

Penyuluhan adalah penambahan pengetahuan dan kemampuan seseorang melalui tehnik praktek belajar atau instruksi dengan tujuan mengubah atau mempengaruhi perilaku manusia secara individu, kelompok maupun masyarakat untuk dapat lebih mandiri dalam mencapai tujuan hidup sehat (Erawati, 2014).

Penyuluhan kesehatan adalah kegiatan pendidikan yang dilakukan dengan cara menyebarkan pesan, menanamkan keyakinan, sehingga masyarakat tidak saja sadar, tahu dan mengerti, tetapi juga mau dan bisa melakukan suatu anjuran yang ada hubungannya dengan kesehatan (Notoatmodjo, 2014).

Penyuluhan pada sasaran kelompok dapat dilakukan pada kelompok ibu hamil, kelompok ibu yang mempunyai anak balita, kelompok masyarakat yang rawan terhadap masalah kesehatan seperti kelompok lansia, kelompok yang ada di berbagai institusi pelayanan kesehatan seperti anak sekolah (remaja), pekerja dalam perusahaan dan lainlain. Penyuluhan pada sasaran masyarakat dapat dilakukan pada masyarakat binaan puskesmas, masyarakat nelayan, masyarakat pedesaan, masyarakat yang terkena wabah dan lain-lain (Surya, 2013).

Penyuluhan dalam penelitian ini bertujuan disamping menambah pengetahuan responden tentang $\mathrm{KB}$ vasektomi juga untuk mendorong minat akspetor untuk menggunakan $\mathrm{KB}$ vasektomi adapun kekhawatiran akan efek samping maka perlu dijelaskan secara baik dan benar kepada responden.

2. Gambaran Minat Calon Akseptor KB Vasektomi di Puskesmas Kedawung Kabupaten Cirebon

Berdasarkan hasil penelitian menunjukkan bahwa sebagian besar responden yang tidak hadir penyuluhan di Wilayah Puskesmas Kedawung Kabupaten Cirebon tidak berminat untuk menggunakan KB vasektomi, sedangkan sebagian besar responden yang hadir penyuluhan di Wilayah Puskesmas Kedawung Kabupaten Cirebon mempunyai minat untuk menggunakan $\mathrm{KB}$ vasektomi.

Vasektomi adalah cara KB permanen bagi pria yang sudah memutuskan tidak ingin mempunyai anak lagi (Meilani, 2013). Vasektomi adalah prosedur klinik untuk menghentikan kapasitas reproduksi pria dengan jalan melakukan oklusi vasa deferensia sehingga jalur transportasi sperma terhambat dan proses fertilisasi penyatuan dengan ovum tidak terjadi (Saifuddin, 2014).

Vasektomi adalah pemotongan vas deferens, yang merupakan saluran yang mengangkut sperma dari epididimis di dalam testis ke vesikula seminalis. Dengan memotong vas deferens, sperma tidak mampu diejakulasikan dan pria akan menjadi tidak subur setelah vas deferens bersih dari sperma (Rahmadi, 2015). Pada pelaksanaan vasektomi ini saluran sel mani yang berfungsi menyalurkan sperma (sel mani) keluar, diikat atau di potong sehingga sperma tidak dikeluarkan dan tidak bisa bertemu dengan sel telur. Dengan demikian bila suami istri melakukan hubungan seksual tidak akan terjadi kehamilan, yang disebabkan karena tidak terjadinya pertemuan antara sperma suami dan sel telur istri (BKKBN, 2013).

Minat merupakan sumber motivasi yang mendorong orang untuk melakukan apa yang mereka inginkan bila mereka bebas memilih. Minat lebih tetap (persisten) karena minat memuaskan kebutuhan yang penting dalam kehidupan seseorang. Semakin kuat kebutuhan ini, semakin kuat dan bertahan pada minat tersebut. Semakin sering minat di 
ekspresikan dalam kegiatan, semakin kuatlah minat tersebut. Minat akan padam apabila tidak disalurkan (Sudarma, 2015).

Minat adalah suatu fungsi jiwa untuk dapat mencapai sesuatu. Minat merupakan kekuatan dari dalam dan tampak dari luar sebagai gerak gerik dalam menjalankan fungsinya. Minat berhubungan erat dengan pikiran dan perasaan (Notoatmodjo, 2012). Penyuluhan mempunyai peran untuk menumbuhkan minat seseorang, karena dengan penyuluhan akan terjadi perubahan penilaian ke arah yang lebih positif sehingga melahirkan minat.

3. Pengaruh Penyuluhan terhadap Minat Calon Akseptor KB Vasektomi di Puskesmas Kedawung Kabupaten Cirebon.

Berdasarkan hasil penelitian menunjukkan bahwa responden yang tidak hadir penyuluhan dan berminat menggunakan KB vasektomi sebanyak 4 orang (10.8\%) lebih sedikit dibanding dengan responden yang hadir penyuluhan dan berminat menggunakan KB vasektomi sebanyak 24 orang $(39,3 \%)$. Hasil penghitungan statistik dengan uji chi square diperoleh $\rho$ value $=0,002$ yang berarti $\rho$ value $<a(0,05)$, sehingga hipotesis nol ditolak. Dengan demikian maka terdapat pengaruh penyuluhan terhadap Minat Calon Akseptor KB Vasektomi di Puskesmas Kedawung Kabupaten Cirebon.

Hasil penelitian ini sejalan dengan penelitian Nesti (2014), faktor-faktor yang berhubungan dengan partisipasi pria dalam pemakaian kontrasepsi di kelurahan Mojosongo kecamatan Jebres menunjukan ada hubungan antara persepsi (nilai $p=0,000$ ) dan dukungan istri (nilai $\mathrm{p}=0,000$ ) terhadap partisipasi pria dalam pemakaian kontrasepsi.

Walaupun vasektomi adalah cara KB paling efektif, tidak mengganggu hubungan seks, aman, dan biaya operasi yang relatif murah, tetapi pada kenyataannya peserta vasektomi lebih sedikit dibandingkan tubektomi (sterilisasi wanita) (Badan Koordinasi Keluarga Berencana Nasional, 2016). Rendahnya partisipasi pria dalam KB dan kesehatan reproduksi pada dasarnya tidak terlepas dari operasional program KB yang selama ini dilaksanakan mengarah pada wanita sebagai sasaran. Demikian juga masalah penyediaan alat kontrasepsi yang hampir semuanya untuk wanita, sehingga pola pikir masyarakat mempunyai persepsi yang dominan yakni yang hamil dan melahirkan adalah wanita, maka wanitalah yang harus menggunakan alat kontrasepsi. Oleh sebab itu, semenjak tahun 2000 pemerintah telah melakukan berbagai upaya untuk meningkatkan partisipasi pria dalam keluarga berencana dan kesehatan reproduksi melalui kebijakan yang telah ditetapkan (Kementerian Kesehatan RI, 2017).

Penggunaan vasektomi kurang dapat berkembang sebagaimana yang diharapkan. Rendahnya minat dalam penggunaan metode kontrasepsi vasektomi diakibatkan oleh adanya kekhawatiran para bapak/ suami setelah vasektomi mereka akan kehilangan kejantanannya. Belum membudayanya penggunaan vasektomi sebagai alat kontrasepsi disebabkan antara lain karena kondisi lingkungan sosial, budaya, masyarakat dan keluarga yang masih menganggap partisipasi pria belum atau tidak penting dilakukan, pengetahuan dan kesadaran pria dan keluarganya dalam ber $\mathrm{KB}$ rendah dan keterbatasan penggunaan pelayanan kontrasepsi pria masih terbatas (Badan Koordinasi Keluarga Berencana Nasional, 2016).

Maka dari itu untuk meningkatkan minat pengguna KB vasektomi maka pihak petugas kesehatan perlu memberikan informasi kepada akseptor tentang KB vasektomi dan memberikan alternatif pemasangan yang baik untuk kondisi akseptor serta memberitahu kepada akssptor untuk melakukan kontrol kepada petugas kesehatan 1 minggu setelah pemasangan atau jika mengalami keluhan.

\section{KESIMPULAN}

Berdasarkan hasil penelitian tentang Pengaruh Penyuluhan Terhadap Minat Calon Akseptor KB Vasektomi di Puskesmas Kedawung Kabupaten Cirebon, dapat diambil kesimpulan sebagai berikut: 
1. Responden di Wilayah Puskesmas Kedawung Kabupaten Cirebon yang tidak hadir penyuluhan tentang KB Vasektomi sebanyak 37 orang $(37,8 \%)$ dan yang hadir sebanyak 61 orang $(62,2 \%)$

2. Responden di Wilayah Puskesmas Kedawung Kabupaten Cirebon yang tidak minat menggunakan $\mathrm{KB}$ vasektomi sebanyak 70 orang (70,7\%) dan yang minat untuk menggunakan $\mathrm{KB}$ vasektomi sebanyak 28 orang $(28,3 \%)$.

3. Terdapat pengaruh penyuluhan terhadap Minat Calon Akseptor KB Vasektomi di Puskesmas Kedawung Kabupaten Cirebon Tahun 2018 dengan p = 0,003.

\section{SARAN}

1. Bagi Puskesmas Kedawung

Untuk meningkatkan minat pengguna $\mathrm{KB}$ vasektomi maka pihak petugas kesehatan perlu memberikan informasi kepada akseptor tentang KB vasektomi dan memberikan alternatif pemasangan yang baik untuk kondisi akseptor serta memberitahu kepada akssptor untuk melakukan kontrol kepada petugas kesehatan 1 minggu setelah pemasangan atau jika mengalami keluhan.

2. Bagi Akseptor KB

Askeptor yang akan memasang $\mathrm{KB}$ vasektomi sebaiknya bertanya atau berkonsultasi terlebih dahulu kepada petugas kesehatan tentang cara pemasangan serta efek sampingnya serta melakukan kontrol atau periksa jika mengalami keluhan setelah dipasang.

3. Bagi Peneliti Lain

Bagi peneliti yang akan datang diharapkan dapat dilanjutkan dengan metode penelitian lainnya atau menambah variabel lain.

\section{DAFTAR PUSTAKA}

Arikunto, Suharsimi. 2013. Prosedur Penelitian Suatu Pendekatan Praktek Edisi Revisi VI. Jakarta: Rineka Cipta.

Arum, Siti. 2013. Panduan Lengkap Pelayanan KB Terkini. Yogyakarta: Penerbit Buku Mitra Cendikia Press.

Azwar, A. 2013. Sikap Manusia, Teori dan Pengukurannya. Yogyakarta. Pustaka Setia.

Badan Koordinasi Keluarga Berencana Nasional. 2013. Kajian Implementasi Kebijakan Penggunaan Kontrasepsi. Jakarta: Pusat Penelitian dan Pengembangan KB dan Keluarga Sejahtera (PUSNA).

2016. KB Sebagai Suatu Kebutuhan. http://www.bkkbn.go.id.,

Cunningham, Gary. 2013. Obstetri Williams. Jakarta : EGC.

Departemen Pendidikan Nasional, 2013. Sistem Pendidikan Nasional. http://www.depdiknas.go.id,

Dinas Kesehatan Provinsi Jawa Barat. 2017. Profil Dinas Kesehatan Provinsi Jawa Barat. Bandung: Dinas Kesehatan Provinsi Jawa Barat.

Handayani. 2013. Buku Ajar Pelayanan Keluarga Berencana. Yogyakarta: Pustaka Rihama.

Hartanto. 2013. Keluarga Berencana dan Kontrasepsi. Jakarta: Pustaka Sinar Harapan.

Irwandi. 2014. Rendahnya Penggunaan Kontrasepsi Vasektomi. www.irwandi.blogspot.com,

Manuaba, IBG. 2013. Ilmu Kebidanan, Penyakit Kandungan dan KB. Jakarta: EGC.

Mubarok. 2013. Promosi Kesehatan Sebuah Pengantar Proses. Yogyakarta: Graha limit

Maulana. 2014. Promosi Kesehatan. Jakarta: Buku Kedokteran EGC.

Nasution, Sri Lilestina. 2014. Faktor-faktor yang Mempengaruhi Penggunaan Kontrasepsi di Indonesia. Jakarta: Badan Kependudukan dan Keluarga Berencana Nasional.

Notoatmodjo, S. 2015. Metodologi Penelitian Kesehatan. Jakarta: Rineka Cipta. . 2012. Promosi Kesehatan dan Ilmu Perilaku. Jakarta : Rineka Cipta

Prawirohardjo, S. 2014. Buku Acuan Nasional Pelayanan Kesehatan Maternal Neonatal. Jakarta: JNPKKR-POGI.

Rahmadi. 2015. Alat Kontrasepsi dan PUS. Yogyakarta: Nuha Medika. 
Saifuddin, AB. 2014. Pelayanan Kesehatan Maternal dan Neonatal. Jakarta: Yayasan Bina Pustaka Sarwono Prawirohardjo.

Sianturi. 2012. Hubungan Faktor Predisposisi Pendukung dan Penguat dengan Tindakan Penggunaan Kondom pada PUS di Kabupaten Serdang Bedagai tahun 2012.

Fakultas Kesehatan Masyarakat Universitas Sumatera Utara.

Sudarma, M. 2015. Sosiologi Untuk Kesehatan. Jakarta: Salemba Medika.

Sugiyono. 2013. Statistik Untuk Penelitian. Bandung: CV. Alfabeta.

Suparyanto. 2013. Umur. http://www.suparyanto/umur/092111/, . 2012. Paritas. http://www.suparyanto/paritas/092112/,

Varney, H. 2013. Buku Ajar Asuhan Kebidanan. Jakarta: EGC.

Widyastuti. 2014. Pelayanan Keluarga Berencana. Yogyakarta: Rohima Press. 